Vol. 3 No.3 (2020) pp. 126-134

Research Paper

\title{
Analysis of Deformation of Float Glass with Heat Treatment in Vehicle Windshield Applications
}

\section{Eko Julianto ${ }^{1}$,Sunaryo $^{2}$, Elkana Bilak Lopo ${ }^{3}$}

${ }^{1}$ Department of Mechanical Engineering, Universitas Muhammadiyah Pontianak, 78123, Indonesia 2Department of Mechanical Engineering, Universitas Sains Al-Qur'an Wonosobo, 56351, Indonesia ${ }^{3}$ Department of Mechanical Engineering, Universitas Nusa Cendana Kupang, 58228 Indonesia

\eko.julianto@unmuhpnk.ac.id

(d) https://doi.org/10.31603/ae.v3i3.3924

Check for updates

\begin{abstract}
Article Info

Submitted:

25/09/2020

Revised:

19/10/2020

Accepted:

22/10/2020

Online first:

$29 / 11 / 2020$

The purpose of this study was to determine the shape change characteristics of float sheet glass using heat treatment experiments on its surface. This involved the use of a float glass type with a thickness of $5 \mathrm{~mm}$, a width of $840 \mathrm{~mm}$, and length of $1350 \mathrm{~mm}$ as the test specimen and the heat transfer experiments and treatment were conducted through conduction with the heat distribution recorded to be between $34{ }^{\circ} \mathrm{C}$ and $600{ }^{\circ} \mathrm{C}$ at every 5 minutes within 60 minutes in a heating furnace. The analysis focused on the characteristics of the glass surface exposed to fire with emphasis placed on the temperature during the deflection changes in the entire glass surface, the dimensional changes at the edges of the glass which follow the glass printing pattern, and the changes in temperature on the upper and lower surfaces of the curved glass mold. The results showed the existence of a very clear change in each temperature or conduction heat when the shape of the glass is changed to curve with the ideal shape observed to have changed at a temperature of $482.50{ }^{\circ} \mathrm{C}$. Moreover, dimensional changes were $1.0427 \mathrm{~m}^{2}$ and the variations in the temperature were $107.55{ }^{\circ} \mathrm{C}$ and the continuous increase in the heat was to have led to a faster change in the glass shape by $11.2^{\circ}$. This, therefore, means a higher temperature or room temperature affects the firing rate of glass bending and also increases the rate of heat absorption.
\end{abstract}

Keywords: Change in deflection; Temperature changes; Wide comparison; Float glass; Heat treatment

\begin{abstract}
Abstrak
Penelitian ini bertujuan untuk mengetahui karakteristik perubahan bentuk kaca float dengan eksperimen perlakuan panas pada permukaannya. Hal ini meliputi penggunaan kaca float dengan ketebalan $5 \mathrm{~mm}$, lebar $840 \mathrm{~mm}$, dan panjang $1350 \mathrm{~mm}$ sebagai benda uji serta perlakuan dan perpindahan panas dilakukan melalui konduksi dengan distribusi panas antara $34{ }^{\circ} \mathrm{C}$ dan $600{ }^{\circ} \mathrm{C}$ setiap 5 menit dalam 60 menit dalam tungku pemanas. Analisis difokuskan pada karakteristik permukaan kaca yang terkena api dengan menitikberatkan pada temperatur selama terjadi perubahan defleksi pada seluruh permukaan kaca, perubahan dimensi pada tepi kaca yang mengikuti pola cetakan kaca, dan perubahan suhu pada permukaan atas dan bawah dari cetakan kaca yang melengkung. Hasil penelitian menunjukkan adanya perubahan yang sangat jelas pada setiap temperatur atau panas konduksi ketika bentuk kaca dirubah menjadi kurva dengan bentuk ideal yang mengalami perubahan pada temperatur $482,50{ }^{\circ} \mathrm{C}$. Selain itu, perubahan dimensi $1,0427 \mathrm{~m}^{2}$ dan variasi suhu $107,55^{\circ} \mathrm{C}$ dan peningkatan panas yang terus menerus menyebabkan perubahan yang lebih cepat pada bentuk kaca sebesar $11,2^{\circ}$. Oleh karena itu, berarti suhu yang lebih tinggi atau suhu ruangan mempengaruhi laju pembakaran dari lengkungan kaca dan juga meningkatkan laju penyerapan panas.

Kata-kata kunci: Perubahan defleksi; Perubahan temperatur; Perbandingan luas; Kaca Float; Perlakuan panas
\end{abstract}




\section{Introduction}

The use of glass is very important in science and industry and its application is very diverse in life due to its transparent and translucent composition as observed in the wide use of its materials in buildings as well as optical, laboratory, and motor vehicle equipment. Glass is made by a mixture of silicon dioxide $\left(\mathrm{SiO}_{2}\right)$ combined with a stabilizer to increase its strength and the manufacturing process has been reported to involve placing the silica material in a furnace at high temperatures of $1500{ }^{\circ} \mathrm{C}$ to $1600{ }^{\circ} \mathrm{C}$ [1].

Glass is a hard and brittle material as well as an amorphous solid which melts easily. It has a hard shape at ordinary temperatures but turns soft and liquid under heat and has been discovered to have a higher compression strength than tensile strength. Moreover, some types produced are usually adjusted to their needs as observed in the glass with a high heat and impact resistance, and its mechanical properties are influenced by the mixture's ingredients and method of production. One type of glass widely used in society is sheet or float glass and its current application is for both buildings and vehicles.

Several studies related to glass resistance test have been conducted and the glass damage caused by radiant heat from inside the heating cabin to the float glass has shown that cracks occur at different seconds according to the thickness of the float glass being tested [2]. Glass is also limited by its higher strength and brittleness when used and this is related to its fracture properties under static and dynamic loads [3]. Moreover, it also contains a functional crystalline phase and glass residue and some of its fraction have been reported to crystallize and vary almost from 0 $100 \%$ [4]. It is, however, important to note that the properties of float glass are strongly influenced by the uniqueness of silica $\left(\mathrm{SiO}_{2}\right)$ and its formation process [5].

Static model testing of float glass is carried out to determine the index of refractive variation. The float glass sheet is cut in sections $150.5 \mathrm{~cm} \times 50 \mathrm{~cm}$ in the shape of equilateral/square. The results showed that untreated glass increased the variability by a factor of 1.29 with a mean of 1.43 (with 95\% probability) and for hard float glass the variability decreased by a factor of 0.63 to 0.69 (with 95\% probability) [6]. Increasing the thickness between layers of glass from $0.38 \mathrm{~mm}$ to $0.76 \mathrm{~mm}$ increased delamination(DS) significantly, whereas an increase for higher thickness between layers had a lower effect [7].

Conventional heat treatment of glass combustion has the same problems with high time and energy consumptions, and lower production costs requiring development for other alternative processes [8]. By controlling the temperature converted into an active thermal system that can react to changing environmental conditions, Laura Baumgartner et al. [9] created a new type of glass, Fluid glass, which combines four functions in one element. The radiation gain from the solar heat from commonly used glass types has been analyzed and measured with measurements then tested with the distribution of solar radiation heat in the room using different types of glass [10].

Glass damage is caused by the increment in stress as a result of increasing temperatures during glass combustion [11],[12]. Meanwhile, the non-linear behavioral characteristics of glass and material properties in glass bending point analysis with natural frequency measurements are usually determined to assess the mechanical response of glass panels [13]. Glass, however, continually absorbs heat by stabilizing the heat to cold due to its thermodynamic instability [14].

There is a need to calculate the temperature distribution and glass stress in the fire [11],[12]. This is due to the brittle failure experienced by the glass without any significant cracking during the pre-coating test [15]. Therefore, heat treatment was developed to improve glass quality and has become a common practice to upgrade glass or gemstones used in representing glass materials after they have been melt into aluminum containers to improve their clarity [16]. Rantala [17] also showed the variation of the thicknesses, heat radiation sources, and physical properties of floating glass, as well as the exposure to radiation of 160.2 to $395.5^{\circ} \mathrm{C}$ from a heat source of 200 to 600 ${ }^{\circ} \mathrm{C}$, has the ability to deform or break the glass. Moreover, the glass plates were heated using thermal flow and forced convection to approximately $640{ }^{\circ} \mathrm{C}$ and the cooling rate depended on the glass thickness, flow, and time coordinates.

This study attempted to test and analyze float glass with heat treatment at a thickness of $5 \mathrm{~mm}$ in 
a heating furnace in reference to the findings of Kumar [5] and Rantala [17]. The heat was applied by burning in a heating furnace for 30-60 minutes while the glass was heated by combustion as reflected on the wall around $400{ }^{\circ} \mathrm{C}$ to $600{ }^{\circ} \mathrm{C}$ to change the shape or cause a deflection for the entire surface of the glass.

\section{Materials and Methods}

The main material used in this research is the float glass in a sheet form with a dimension of $1350 \mathrm{~mm} \times 840 \mathrm{~mm} \times 5 \mathrm{~mm}$ and having the physical and mechanical properties listed in Table 1. The research was conducted in two stages which are glass bending and its subsequent test. Moreover, the temperatures used in the glass bending process were varied to determine the optimal limit of the bending temperature and the type of glass. The dimension of the windshield used as test specimens includes a thickness of 5 $\mathrm{mm}$ as presented in Figure 1.

The windshield printing started with the cutting of the glass according to the size and shape of the previously measured mold on the front side of the minibus with a radius of approximately $10^{\circ}$ to $1^{\circ}$ for the right and left side of the glass as presented in Figure 2. The glass bent and follow the print pattern in the furnace after a temperature of $400{ }^{\circ} \mathrm{C}$ and pressed using the designed steel. The float glass type was, therefore, analyzed for heat transfer and quality using the windshield mold in Figure 2. Meanwhile, Figure 3 shows the process of burning and bending glass in a hightemperature heating furnace.

Table 1. Physical and mechanical properties of float glass [18],[19].

\begin{tabular}{clcc}
\hline No & \multicolumn{1}{c}{ Type } & Value & Unit \\
\hline 1 & Specific heat & 250 & $\mathrm{~J} / \mathrm{kg} . \mathrm{K}$ \\
2 & Reflection index & 4 & $\%$ \\
3 & Heat type & $0-50$ & ${ }^{\circ} \mathrm{C}$ \\
4 & Soft point & $720-730$ & ${ }^{\circ} \mathrm{C}$ \\
5 & Heat conduction & 0.68 & $\mathrm{kcal} / \mathrm{mhr}^{\circ} \mathrm{C}$ \\
6 & The coefficient of linear expansion & $8.5^{-9} \times 10^{-6}$ & ${ }^{\circ} \mathrm{C}$ \\
7 & Specific gravity & 2500 & $\mathrm{~kg} / \mathrm{cm}^{2}$ \\
8 & Modulus young & 720.000 & $\mathrm{~kg} / \mathrm{cm}^{2}$ \\
9 & Poisson's number & 0.25 & $\mathrm{~V}$ \\
10 & Breaking voltage & 350 & $\mathrm{~kg} / \mathrm{cm}^{2}$ \\
\hline
\end{tabular}

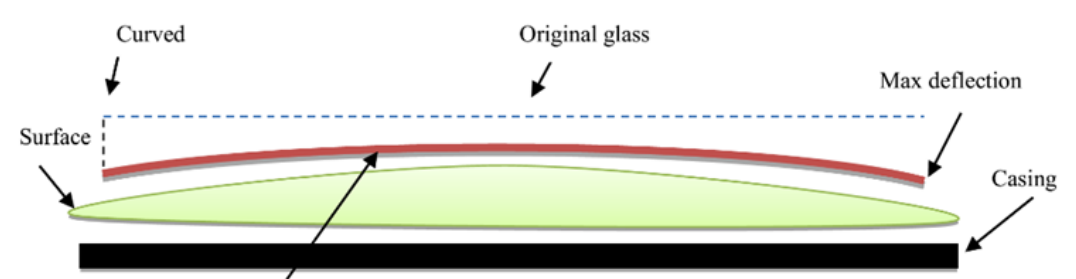

Max thicknes

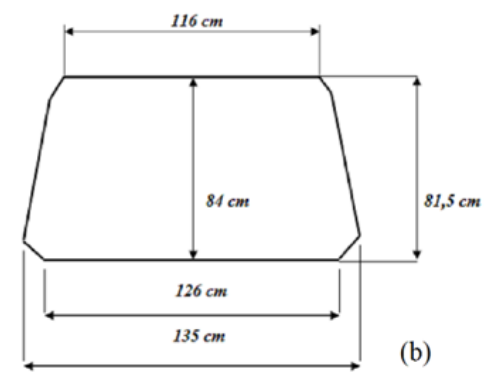

Figure 1. Test specimen: (a) Change in shape of the windshield glass and (b) Dimensions of the initial glass
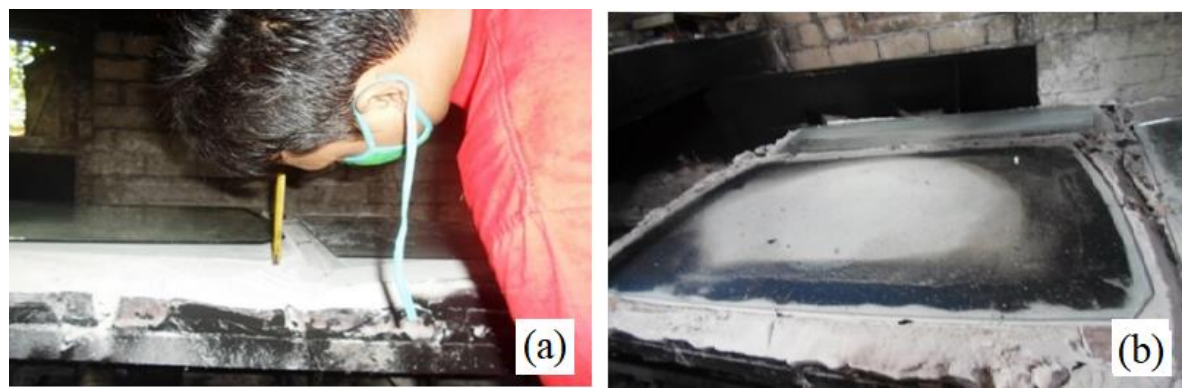

Figure 2. Mold Specimens: (a) Mold height Measurement on the glass and (b) Glass sheet on the mold top 

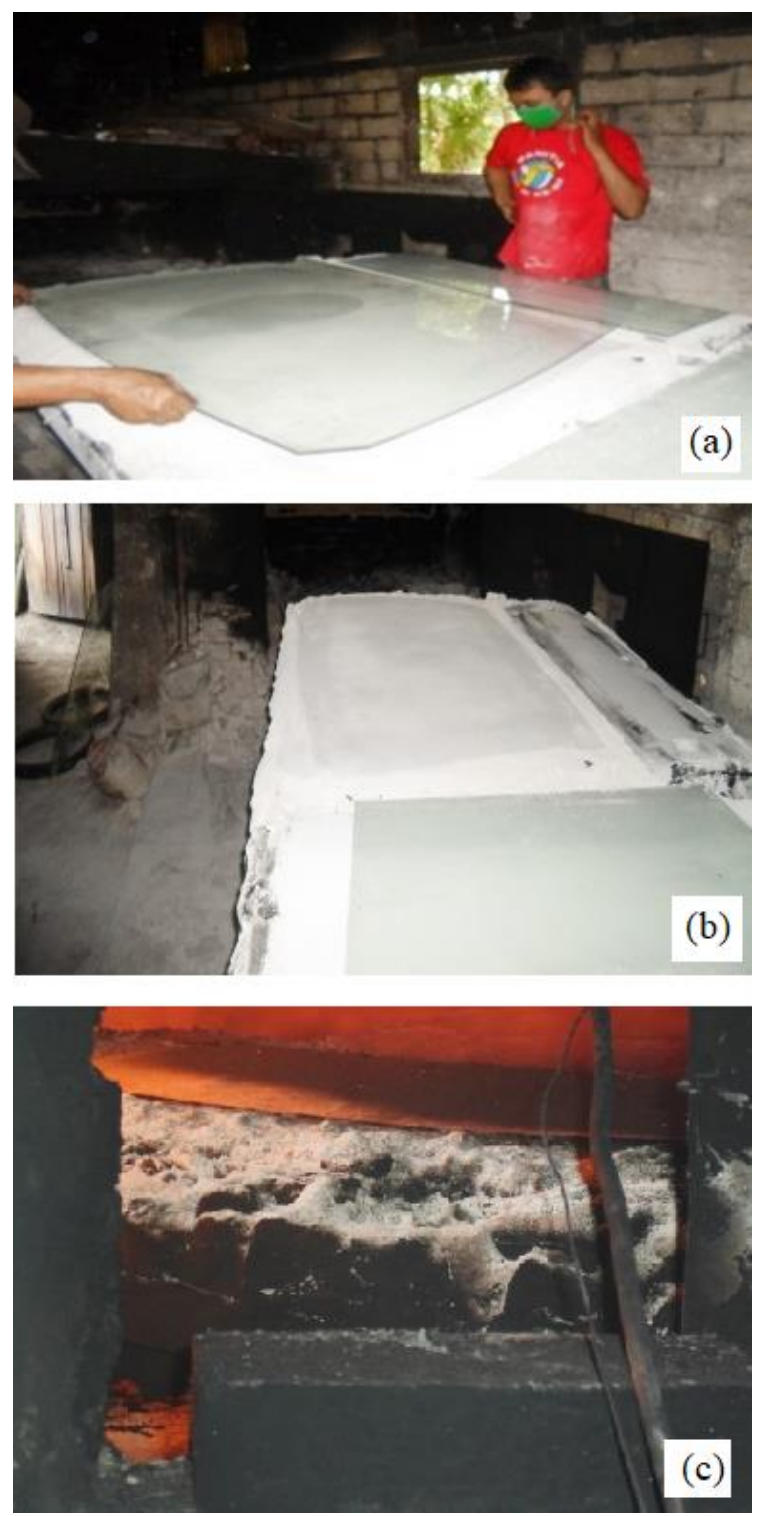

Figure 3. Mold and furnace: (a) glass on the mold, (b) heating furnace, and (c) fire control door

Glass curvature testing is carried out on heat variations from minimum temperature to temperature when the glass is deformed (curved). The parameters tested are:

a. The temperature of the heating room against the changes in glass or deflection after being exposed to heat radiation reached the ideal value $(\Delta L)$. The temperature distribution of the glass changes is distributing heat in the heating room and glass therefore it curves into elasticity. The temperature change in the heating room and the entire sheet surface are evenly distributed therefore zthe glass experiences changes called the ideal temperature. All glass variations were tested for heat damage and their structures have the ability to be in the form of a concentrated or more diffuse thermal surge with a higher glass composition and atomic ratio.

b. The cross-sectional area affected the changes in temperature and glass firing time $(\Delta A)$ and this was observed from the flat sheet glass becoming curved after stretching due to the higher heating required for wider dimensions. The temperature was converted into an active thermal system capable of reacting to changing environmental conditions according to Laura Baumgartner et al. [9].

c. The amount of heat entering or exposed to the glass surface is observable from the beginning using a heat gauge $(\Delta T)$. This involves heating of the glass sheet by thermal flow and forced convection to approximately $640{ }^{\circ} \mathrm{C}$ and then cooling depending on the thickness of the glass at flow and time coordinates [17]. However, there is a possibility of the glass breaking in case the surface is suddenly exposed to extreme heat or shock [12].

d. The changes in deflection due to heat treatment caused the glass structure to change shape and become elastic $(L)$ or to deflect downward by becoming curved following the print pattern on the heating furnace as shown in the bending direction of Figure 1 .

\subsection{Heat Exchanger Effectiveness}

An effective method was used to compare different types of heat exchangers in order to select the best for a particular heat transfer. The effectiveness of a heat exchanger is defined in Eq.(1). $\Delta T$ is the temperature difference in the heat exchanger, $T_{1}$ is intake temperature, and $T_{2}$ is exit temperature [20].

$$
\Delta T=\left(T_{2}-T_{1}\right)
$$

The actual heat transfer was calculated from the energy released by the hot fluid or the energy received by the cold fluid for the counter-flow heat exchanger using Eq.(2). Where, $q$ is heat transfer, $M$ is heat flow, $C_{h}$ specific heat and $C_{c}$ is specific cold, $T_{h}$ and $T_{c}$ are intake and exit temperature, respectively [20],[21].

$$
q=M_{h} C_{h}\left(T_{h 1}-T_{h 2}\right)=M_{c} C_{c}\left(T_{c 1}-T_{c 2}\right)
$$

Fluid with greater value experiences a maximum temperature difference. Other types of fluid also experience a temperature greater than the fluid that is greater or the maximum, and this is not possible [20]. Therefore, the maximum 
possible heat transfer is expressed by Eq.(3). Where, $U$ is heat transfer coefficient, $A$ heat transfer surface area and $\Delta T_{m}$ is difference in average temperature in heat exchanger.

$q=U \cdot A \cdot \Delta T_{m}$

\subsection{Arch Quality of Glass}

The analysis of the quality curved glass showed the float glass is the stronger and more resistant type to solar heat radiation, collisions, or vibrations caused by vehicles running on bumpy roads and can withstand solar heat radiation of approximately $45{ }^{\circ} \mathrm{C}$ or maybe even hotter [10],[18],[19].

\section{Result and Discussion}

The test conducted on the float glass to be curved with different variations of heat conduction from normal or minimum to the maximum showed the changes in the initial heating time up to the period the bending or deformation was achieved.

\subsection{Deflection Change Temperature $(\Delta L)$}

The changes in the deflection temperature due to the heat distributed on the glass surface affected the shape of the strain on the glass and continuously depends on the heat generated in the Furnace room.

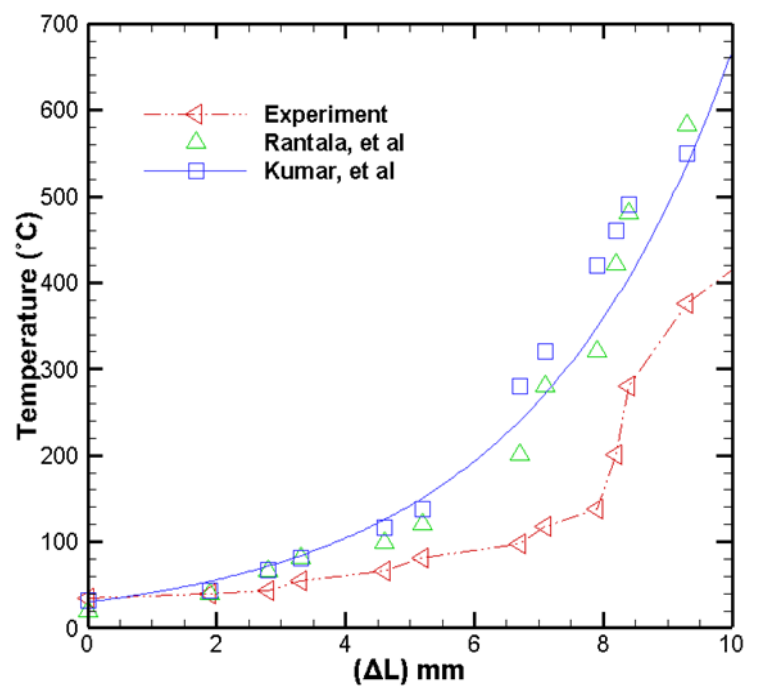

Figure 4. The effect of temperature changes on the glass shape of this experiment, compared with the results of the research by Kumar [5] and Rantala [17]

Figure 4 shows the deflection of the glass increases with the temperature after exposure to heat up to a maximum or ideal temperature of $482.5^{\circ} \mathrm{C}$. This change in the shape of the glass is in line with the studies of Rantala [17] and Kumar [5] which showed the effect of different thickness of the glass on given heat distribution and the temperature which produced the curved glass at the same thickness was considered ideal. The data validated with previous research indicated the results of the glass experiment change shape and there is a change in deflection, namely the temperature is below the average of the results of previous studies from $32{ }^{\circ} \mathrm{C}$ to $600{ }^{\circ} \mathrm{C}$ and is inconsistent with previous studies, due to the standards of each thickness and glass production in each country different. Therefore, the heat absorption of each glass surface is also different.

\subsection{Area Ratio $(\Delta A)$}

Figure 5 shows the ratio of area to time using experimental data and the cross-sectional area was found to have an effect on the changes in temperature and glass firing time. The prediction data of the experimental method produced systematically calculated data and a greater temperature was observed to be causing a faster glass bending process.

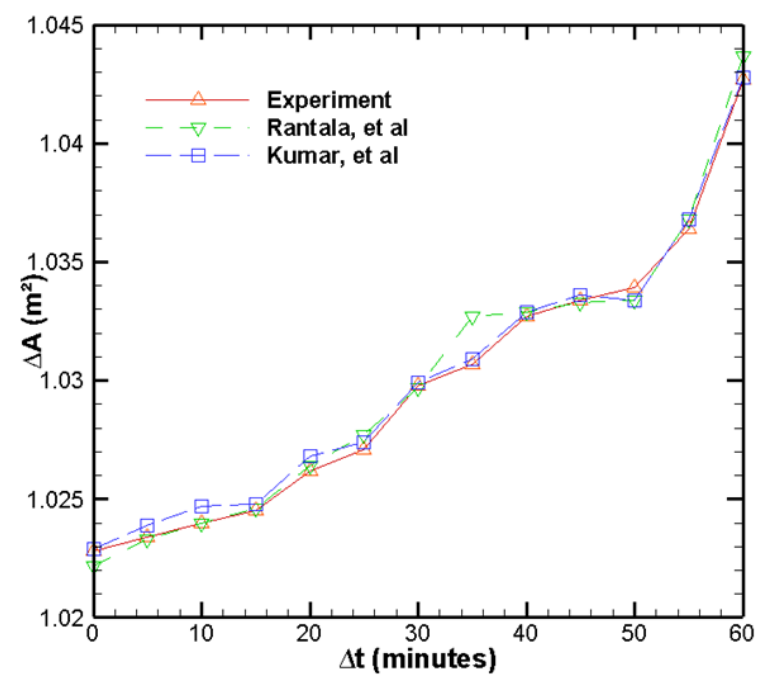

Figure 5. Comparison of cross-sectional areas at a time of this experiment, compared with the results of the research by Kumar [5] and Rantala [17]

Figure 5 shows the effect of $\Delta A$ or the ratio of the area on the changes in temperature per minute, the dimensions of the glass stretch along with changes in the surface temperature of the glass started stretching and experienced elasticity due to the heat distributed directly onto the surface of the glass. The changes in the area were found to be $1.0427 \mathrm{~m}^{2}$ while previous studies 
conducted by Rantala [17] and Kumar [5] showed the changes in glass area affected the distribution of the heat generated during the combustion process in the Furnace room by $1.0437 \mathrm{~m}^{2}$ and $1.0428 \mathrm{~m}^{2}$ as indicated in the graph. This means the results of the experiment are consistent with the findings of the previous studies.

\subsection{Change in Temperature $(\Delta T)$}

The change from the initial to ideal glass temperature $(\Delta T)$ between the glass walls in the room in the $5^{\text {th }}$ minute, the first temperature was $278.4{ }^{\circ} \mathrm{C}$ while the final temperature in the $60^{\text {th }}$ minute was $380.7{ }^{\circ} \mathrm{C}$ (see Figure 6). Moreover, there was a difference in the temperature inside and outside the heater on the walls of the combustion chamber but the heat on the glass wall was found to be higher in temperature than the air around the inner heating wall. This is observable from the beginning of the incoming glass which was estimated at $34.0^{\circ} \mathrm{C}$ up to the period it turned into a curved glass at approximately $482.0^{\circ} \mathrm{C}$.

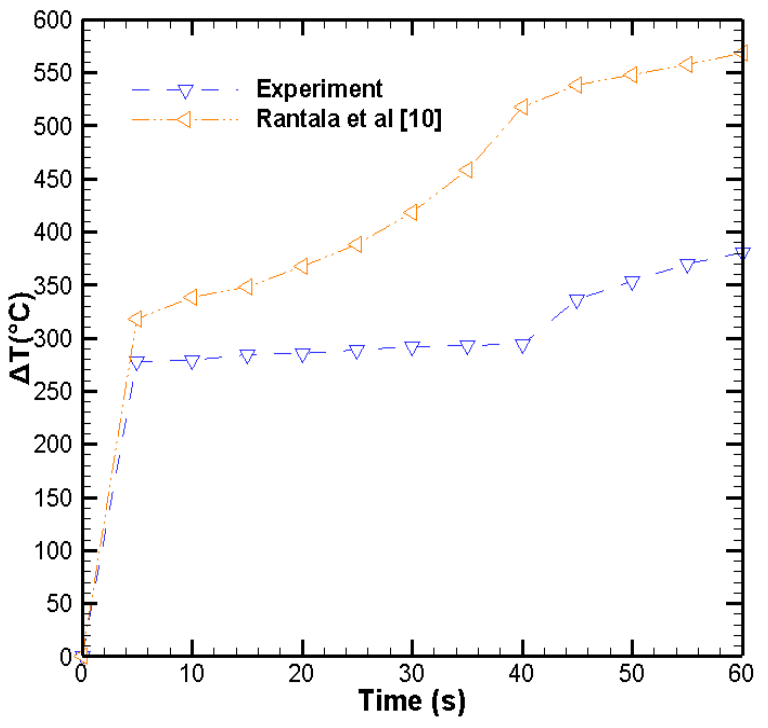

Figure 6. Temperature change graph of this experiment compared with Rantala [17].

Figure 6 shows the results of previous glass studies are not consistent with the values obtained from the experiments conducted due to the possible differences in the ideal temperature for each furnace and the thickness of the glass. Previous studies reported an average temperature of $568^{\circ} \mathrm{C}$ [17]. while the experiment had $380.7^{\circ} \mathrm{C}$.

In the temperature change from the initial glass temperature $32{ }^{\circ} \mathrm{C}$ until the temperature in the furnace reaches $400{ }^{\circ} \mathrm{C}$ with a thickness of $5 \mathrm{~mm}$ under conduction heat treatment. Therefore, it turns into curved glass or changes in deflection. After the glass is heat treated, the glass will be cooled naturally by convection.

\subsection{Dimensional Profile of Deflected Glass (L)}

The changes in the variable at room temperature to changes in the shape of the glass deflection after being exposed to heat until it reaches the ideal or maximum temperature. Therefore, the glass undergoes a change in deflection from the initial bending of $1.9^{\circ}$ to $11.2^{\circ}$ which changes shape from flat to curved according to the mold that has been previously formed in the room heating.

The changes observed in the shape of the glass corners due to the expansion of the glass material exposed to direct fire on the furnace room led to the change in the glass structure and ensure it becomes elastic with the side discovered not to be resting on the mold. Therefore, Figure 7 shows the corner points changed the deflection from a presumed $0^{\circ}$ or start of the glass to a maximum bending of $11.2^{\circ}$ and a low and uneven change in the temperature has the ability to break the glass during firing.

From the reserch of the temperature change at each temperature was very clear when the glass changes shape or warps. Meanwhile, the burning of float sheet glass was measured using a heat gauge or thermocouple up to the moment the glass was formed based on the ratio of temperature or heat rate for continuous burning. The value was observed to be increasing and reached the average maximum value of $482.5^{\circ} \mathrm{C}$ during the combustion process. This process proves the role of the heating stove as a heat sink for refractory bricks, stone, and silica sand as well as the heat-resistant cement coating in the combustion chamber. The average or minimum initial temperature during the test was found to be $146.7^{\circ} \mathrm{C}$ and the variation of the conduction heat source thickness and float glass physical properties with 160.2 to $395.5^{\circ} \mathrm{C}$ exposure from a heat source of $200-600{ }^{\circ} \mathrm{C}$ observed to have caused the glass to deform or break [22]. A higher and denser room temperature also affected burning rate for the glass sheet bending as observed with the data presented in Table 2 where the heat absorption rate in the combustion of float sheet glass was higher. 
Furthermore, a change was discovered in the deflection at each time check and this means curving of the glass was influenced by outside and inside temperatures of the Furnace room or combustion chamber. The bending of float sheet glass was tested for 1 hour and the quantity of fuel was reduced every 5 minutes up to the moment the shape was changed. Meanwhile, a value of $42.7^{\circ} \mathrm{C}$ was, however, obtained to cool the glass using a natural process.

Table 2. The Measurement and calculation of temperature

\begin{tabular}{ccccc}
\hline \multirow{2}{*}{ Minute } & \multicolumn{2}{c}{ Temperature $\left({ }^{\circ} \mathrm{C}\right)$} & \multirow{2}{*}{$\Delta \mathrm{L}$} & \multirow{2}{*}{$\Delta \mathrm{A}\left(\mathrm{m}^{2}\right)$} \\
\cline { 2 - 3 } & $\mathrm{In}$ Glass & $\Delta \mathrm{T}$ & 0 & 1.0228 \\
10 & 34.9 & 0 & 1.9 & 1.0234 \\
15 & 39.3 & 278.4 & 2.8 & 1.024 \\
20 & 44 & 278.7 & 3.3 & 1.0245 \\
25 & 55 & 285 & 4.6 & 1.0262 \\
30 & 66.3 & 285.3 & 5.2 & 1.0271 \\
35 & 80.7 & 288.4 & 6.7 & 1.0298 \\
40 & 98.2 & 291.5 & 7.1 & 1.0307 \\
45 & 117.8 & 293.6 & 7.9 & 1.0327 \\
50 & 138.5 & 294.7 & 8.2 & 1.0334 \\
55 & 200.3 & 335.8 & 9.3 & 1.0339 \\
60 & 375.8 & 353.9 & 11.2 & 1.0427 \\
\hline
\end{tabular}
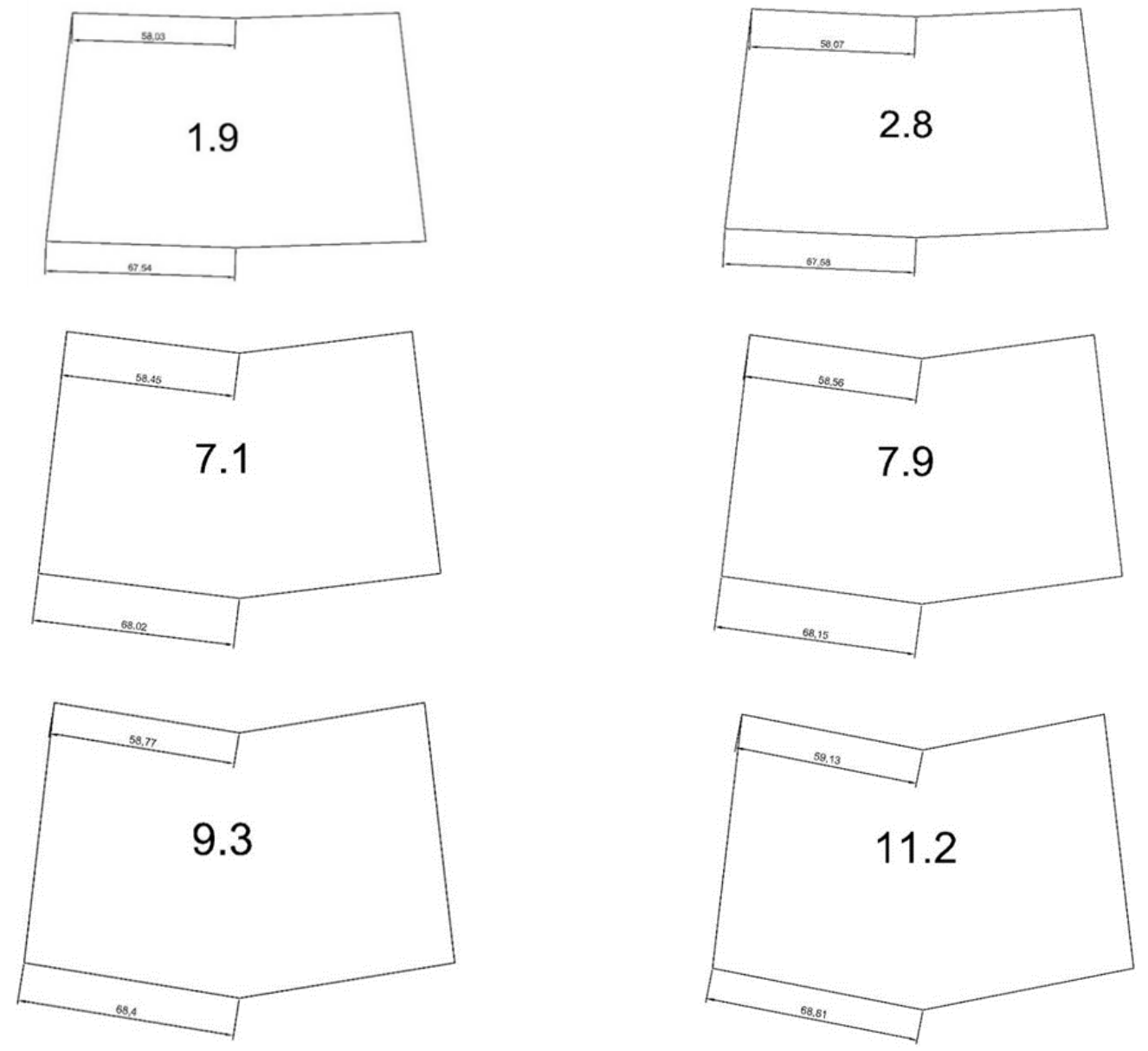

Figure 7. Change in deflection 


\subsection{The Quality of the Glass Arch}

The quality test for the glass curves showed the dominant types of sheet glass and the float type was observed to be stronger than solar thermal radiation, collisions, or vibrations caused by road vibrations on vehicles running on uneven surfaces. It also has the ability to withstand more solar heat radiation and those lesser than 40 to 50 ${ }^{\circ} \mathrm{C}$ have the potential to be better than manufactured glass.

Figure 8 shows the quality of the glass arch is very good, looks perfect, and easy to install on the vehicle glass frame. The drawback of the curved float glass compared to tempered and laminated curved ones is that when it breaks, the crack is spread from the corner of the side to the middle. Moreover, it does not have what is called thousand broken pieces like laminated and tempered glass which broken pieces are shaped like small seeds such as sand or coarse rock. It was, however, recommended that curved float glass is coated with window film for good quality and safety to ensure it withstands vibrations and solar heat radiation effectively and prevent it from endangering motorists and vehicle users when broken.
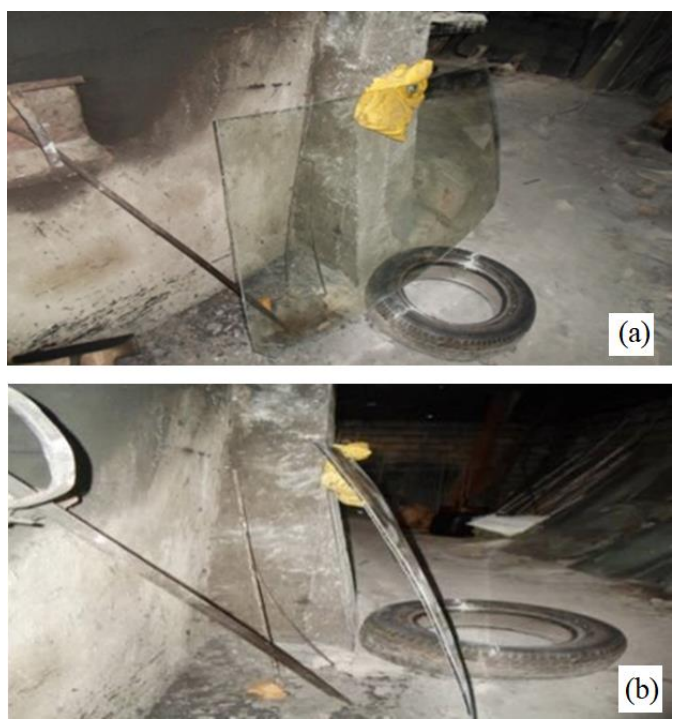

Figure 8. Curved quality of glass: (a) Curved front view and (b) Side view

\section{Conclusion}

The test showed there is a very clear change in each temperature or heat of conduction when the glass changed to curved glass. The combustion process was measured carefully using a thermocouple or heat measuring device up to the period the glass changed into a curve and the change in deflection of the glass $(\Delta L)$ was found to be affected by the exposure to heat and an ideal temperature was reached. Moreover, the results were validated using the findings of previous studies, and the change in $\Delta L$ deflection was found to be below the average while the ratio of the area in $\mathrm{m}^{2}$ was very consistent with the previous findings. The area ratio $(\Delta A)$ was also observed to significantly change with the temperature per minute and this led to the glass deflection. Furthermore, the heat flow rate of combustion for the bending glass was affected by high room temperature or heat and this is confirmed by the higher heat absorption rate recorded by the float glass combustion at approximately 60 minutes while the glass was cooled after the bending using the natural value of $42.7^{\circ} \mathrm{C}$. This, therefore, means the temperature change at each corner and part of the glass directly exposed to heat in the internal combustion chamber was very efficient in the deflection change process while the glass mold also has a significant role in determining the shape of the glass to be used in a vehicle.

\section{Acknowledgement}

This research was supported by the Universitas Muhammadiyah Pontianak (UM Pontianak), Universitas Sains Al Quran Wonosobo (UNSIQ), and Universitas Nusa Cendana Kupang, Indonesia.

\section{Author's Declaration}

\section{Authors' contributions and responsibilities}

The authors made substantial contributions to the conception and design of the study. The authors took responsibility for data analysis, interpretation and discussion of results. The authors read and approved the final manuscript.

\section{Funding}

This research has been funded by the Universitas Muhammadiyah Pontianak, Universitas Sains al Qur'an and Universitas Nusa Cendana Kupang.

\section{Availability of data and materials}

All data are available from the authors.

\section{Competing interests}

The authors declare no competing interest.

\section{Additional information}

No additional information from the authors. 


\section{References}

[1] K. Tapasa and T. Jitwatcharakomol, "Thermodynamic calculation of exploited heat used in glass melting furnace," Procedia Eng., vol. 32, pp. 969-975, 2012.

[2] Y. Zhang, Q. S. Wang, X. Bin Zhu, X. J. Huang, and J. H. Sun, "Experimental study on crack of float glass with different thicknesses exposed to radiant heating," Procedia Eng., vol. 11, pp. 710-718, 2011.

[3] A. Nyounguè, S. Bouzid, E. Dossou, and Z. Azari, "Fracture characterisation of float glass under static and dynamic loading," Journal of Asian Ceramic Societies., vol. 4, no. 4, pp. 371-380, 2016.

[4] J. Deubener et al., "Updated definition of glass-ceramics," J. Non. Cryst. Solids, no. January, pp. 1-8, 2018.

[5] R. V. Kumar and J. Buckett, "Float Glass ," Ref. Modul. Mater. Sci. Mater. Eng., no. February 2015, pp. 1-8, 2017.

[6] K. P. Rushton, S. A. Coulson, A. W. N. Newton, and J. M. Curran, "The effect of annealing on the variation of glass refractive index," Forensic Sci. Int., vol. 209, no. 1-3, pp. 102-107, 2011.

[7] A. Vedrtnam, "Experimental and simulation studies on delamination strength of laminated glass composites having polyvinyl butyral and ethyl vinyl acetate inter-layers of different critical thicknesses," Def. Technol., pp. 1-5, 2018.

[8] P. Stief, J. Dantan, A. Etienne, and A. Siadat, "New process of tempering color printed glass by using laser irradiation," Procedia CIRP, vol. 74, pp. 390-393, 2018.

[9] L. Baumgärtner, R. A. Krasovsky, J. Stopper, and J. Grabe, "Evaluation of a solar thermal glass façade with Evaluation of a solar thermal glass façade with adjustable in of cold and hot climates," Energy Procedia, vol. 122, pp. 211-216, 2017.

[10] C. Zheng, P. Wu, V. Costanzo, Y. Wang, and $X$. Yang, "Establishment and Verification of Solar Radiation Calculation Model of Glass Daylighting Roof in Hot Summer and Warm
Winter Zone in China," Procedia Eng., vol. 205, pp. 2903-2909, 2017.

[11] Q. S. Wang, Y. Zhang, J. H. Sun, J. Wen, and S. Dembele, "Temperature and thermal stress simulation of window glass exposed to fire," Procedia Eng., vol. 11, pp. 452-460, 2011.

[12] Q. Wang, H. Chen, Y. Wang, and J. Sun, "Thermal shock effect on the glass thermal stress response and crack propagation," Procedia Eng., vol. 62, pp. 717-724, 2013.

[13] L. Sable, E. Skukis, G. Japins, and K. Kalnins, "Correlation between numerical and experimental tests of laminated glass panels with visco-elastic interlayer," Procedia Eng., vol. 172, pp. 945-952, 2017.

[14] J. C. Mauro and M. M. Smedskjaer, "Statistical mechanics of glass," J. Non. Cryst. Solids, vol. 396-397, pp. 41-53, 2014.

[15] B. W. Stuart, M. Gimeno-fabra, J. Segal, I. Ahmed, and D. M. Grant, "Applied Surface Science Mechanical, structural and dissolution properties of heat treated thinfilm phosphate based glasses," Appl. Surf. Sci., vol. 416, pp. 605-617, 2017.

[16] G. Tunjai, A. Chotipong, and C. Sutthirat, "The Leachate of Lead from the Crucibles Undergone Ruby Heat Treatment with Lead Glass Additive," Procedia - Soc. Behav. Sci., vol. 10, pp. 91-95, 2014.

[17] M. Rantala ,"Heat Transfer Phenomena in Float Glass Heat Treatment Processes," (Tampere University of Technology. Publication; Vol. 1355). Tampere University of Technology.

[18] Asahimas Flat Glass tbk, "Architectural Glass." 2020.

[19] Badan Standardisasi Nasional (BSN), "Kaca lembaran," SNI 15-0047-2005.

[20] M. C. Potter and C. W. Somerton. "Schaum's Outline of Thermodynamics for Engineers, "Second Edition. McGraw-Hill, 2010.

[21] D. R. Pitts and L. E. Sissom. Theory and problems of heat transfer. McGraw-Hill, 1977.

[22] E. Julianto, W. A. Siswanto, and M. Effendy, "Characteristics of temperature changes and stress of float glass under heat radiation," Int. J. Emerg. Trends Eng. Res., vol. 7, no. 9, 2019. 